\title{
THE DEVELOPMENT OF TRANSLATION STUDIES IN UZBEKISTAN
}

${ }^{1}$ Jamila Shariyevna Karimova, ${ }^{1}$ Ezoza Khasanovna Khalmurodova, ${ }^{1}$ Nazokat Karimbaevna Sabirova, ${ }^{1}$ Victoria Yurevna Smirnova, ${ }^{1}$ Saida Abdusamatovna Egamberdiyeva

${ }^{1}$ Lecturer of the Department of English Language, Tashkent Institute of Irrigation and Agricultural Mechanization Engineers, Tashkent, Uzbekistan.

\section{ABSTRACT}

The language of every nation is the most unique and perfect treasure in its historical development. Language reflects the destiny of the people, their way of life and their spiritual wealth. Language is a unique and never-fading mirror of the nation's spirit. In every language, the level and psyche of the nation that speaks this language is vividly expressed. For this reason, every nation is constantly concerned about the purity, perfection and development of the native language. In this article, we shall discuss the translation as an art and the history and development of translation studies in our country.

Keywords:

Translation, Fundamentals of Translation Theory, Department of Translation, Persian Letters, the Art of Poetic Translation, the problems of translation

Article Received: 18 October 2020, Revised: 3 November 2020, Accepted: 24 December 2020

\section{Introduction}

In the Uzbek literature of the independence period, as in all genres, there is a clear change in the practice of literary translation. It is especially gratifying that the translation from the original language is being followed. It is very encouraging that young people are testing their talents and boldly translating samples of Eastern and Western literature directly into our native language.

In the history of world civilization, the twentieth century is called the "century of translation" (P.-F. Kaye). Nafsilambr, the Uzbek translation with a thousand-year history, is also unprecedented in the last centuryachieved results, acquainted our people with the royal works of world literature. For centuries, from Cholpon's Shakespeare (Hamlet), Osman Nasir's Lermontov (Demon),Oybek's translations from Pushkin (Eugene Onegin), ErkinVahidov's Goethe (Faust), Abdulla Aripov's Dante (Hell), KadyrMirmuhamedov's Homer (Iliad) were important events in the history of our literature and became stable translations of works into our native language.

By the second half of the twentieth century, new directions such as scientific translation, machine translation, and simultaneous translation emerged behind the concept of literary translation. It is important to evaluate the quality of translated works the science of translation theory has emerged. By the seventies of the last century, the higher education of the republic the course of translation theory and practice was taught at the faculties of philology and journalism.

The Section of Literary Translation under the Writers' Union of Uzbekistan, the Section of Translation Theory at the Institute of Language and Literature of the Academy of Sciences, and the Department of Translation Theory at Tashkent State University (now the National University of Uzbekistan) has been launched.

Independence, like all aspects of artistic creation, has opened a wide way for translation, creating opportunities for our translators and translators to go out into the world. It is no exaggeration to say that in the last twenty-five years we have entered the world arena in the field of fine arts, music and song. But we have not yet found our place in the world literary process in the creation of highly artistic and translated works. Ultimately, our translation, with its rich experience and capabilities, experienced a period of stagnation in the early years of independence. I want to say that during these years, our translators 
studied in Moscow (1993), London (1995),He did not attend the congresses of Gettengen (1996), Melbourne (1998), Vancouver (2002), and Tampere (2005)studies (except for K. Musaev's "Fundamentals of Translation Theory" (2005) and B. Ilyasov's monograph "The Art of Poetic Translation" (2007). The annual reports of the translation section under the Writers 'Union have also lost their previous creative impetus.

However, in the first years of independence, the embassies of France, Germany, England, the United States and India, which began their work in our country, translated into Uzbek the works of famous writers' translation, creation of textbooks and dictionaries in English, German, French, Hindi for Uzbek schools. In particular, the initiative of the Goethe Institute under the German Embassy, the Institute for Central Asian Studies under the French Embassy and the Victor Hugo Center in this area should be noted. For example, with the support of the French Embassy in Tashkent, in recent years, the French

Materials and methods

Voltaire's "Zadig", F. Moriak's "In the Claws of Snakes", Montesquieu's "Persian Letters", Le Clezio's "Mondo and Other Stories", Charles Perrault's "Fairy Tales" were translated into Uzbek and published in 1997. The establishment of the literary magazine was a great event. For the past eighteen years, the magazine has been effective in introducing Uzbek readers to examples of world literature. It is worth mentioning the initiative of the well-known literary critic and translator, teacher OzodSharofiddinov. During his lifetime, the teacher paid special attention to the content of the magazine, increased the demands on the quality of translations and articles published in it, and took great responsibility.

Therefore, in recent years, the journal has undergone significant changes in the world literary process, avant-garde currents and schools,

He has also published in-depth articles on the practice and theory of translation, and has regularly translated translations of works by world-renowned writers, beggars in today's literary process, and winners of international Nobel Prizes in literature. Indeed, today's reader is from English literature by John Golsworthy, SommersetMoem, Thomas Sternz Eliot, Richard Oldington, Oldos Huxley, Evelyn Vo, Iris Mèrdok; from American literature William Faulkner, Ernest Hemingway, John Steinbeck, Richard Wright, John Updike, David Selinger, William Stayron; French literature Guillaume Apollinaire, Marcel Proust, Andre Jid, Antoine de Saint Exupery, Albert Camus, François Moriak, Natalie Sarrot, Claude Simon, Jean-Marie Gustave Le Clezio, Patrick Modiano, German literature Thomas Mann, Lion Feitchtwanger, Arion Brext, German Gesse, Heinrich Bèll, Krista Wolf, Günter Grass; as well as read translations of works by Jorge Luis Borges, Gabriel Garcia Marquez, Umberto Eco, Julio Cortasar, Alexo Carpenter, Kazuo Isiguro, Mo Yan, Lao She, Haruki Murakami. Gegel, Kerkegor, Nietzsche, M.Baxtin, R.Bart, Jose Ortega-iGasset, M.Haydegger, A.F. Losev has been getting acquainted with the views of others on literature and the literary process through the magazine.

The magazine publishes translations of works of foreign writers from Russian editions into our language. From now on, "World Literature" should become a publication that promotes direct translations from the original. For example, in previous yearsthe magazine featured examples from the work of medieval French poet François Villon, English and American Romantic poetry beggars George Byron, and Edgar Allan Poe. A reader unfamiliar with the original and Russian translation texts, reading the above translations, came to the conclusion that Vienna, Byron, Edgar Allan Poe were in fact so crushed. However, when we replace these translations with the original and Russian translation texts, we observe how freely our poetic translators moved, and as a result, how far they moved from the original. True, there is a saying in the translation of poetry that the translator becomes the opponent of the author. This means that the translator can 
write a poem in sync with the text of the original in the native language, but does not give the concept of tribe.

For example, Edgar Allan Poe's poem "The Great Timur" (Tamerlan, 1827) is translated by the Russian poet Valery Bryusov as follows:

Заката сладкая услада!

Отец! я не могу признать, Чтоб власть земная - разрешать

Могла от первой казни ада.

Куда пойду за гордость я

Что спорить нам: слова пустые!

And translator translate it like this:

The comfort is unbearable.

Dad, why comfort in this ball?

Yours, the words on Earth will not come

To the just punishments of Hell

I know, my hellish arrogance,

Stop, don't fertilize, torture me a lot.

This is how the poem of the English poet George Byron "On my Day I complete my Thirtysixth year, 1824" in the translation of $\mathrm{Z}$. Morozkina sounds like this.

Других не властный волновать,

Я сам бесстрастен должен быть.

Но и без отклика, опять

Хочу любить.

Some poets wrote that they translated from Russian, while Abdul Hamid did not say from which language he translated. It is clear how far all three translations have moved away from the Russian text in place of the original. We compared the above four with the English text, perhaps wondering if Abdul Hamid had made his own translations from the original. However, it is also clear that it is far from the English text. In the English text, the poem has the same content and appearance as in the Russian translation:

It is time this heart should be unmoved,

Since others it hath ceased to move:

Yet, though I cannot be beloved,

Still let me love!

The bottom line is that we now need to move directly from the original language to the translation. The first direct translations appeared in the last quarter of the last century by Yanglish Egamova, Sadriddin Salimov, Sharofat Botirova and Victor Hugo's "Songs of the East", Garj's collection of "The Saddest Song" by F. GarciaLorca, originally translated by Shavkat Rahmon. Our poets Jamal Kamal and Abdullah Sher also used the original as much as possible in translating Shakespeare and Byron dramas. However, in the words of translator Zuhriddin Isomiddinov, the time has come when translation from foreign literature is in full swing. Hundreds of them have graduated in the last fifteen years. There are only four or five dedicated translators and interpreters among them. According to Nosir Qambarov, the former dean of the translation faculty at Uzbekistan State World Languages University (UzSWLU), this is due to the fact that "the theoretical problems of translation from foreign languages into Uzbek have not been fully resolved, and textbooks and manuals have not been published." There is life in the teacher's words. So far, no textbook on the practice of translation from foreign languages into Uzbek and from Uzbek into foreign languages has been published in the country. Translators from UzSWLU and Samarkand State University such as Ibrahim Gafurov, Nizam Kamilov, Jamol Kamol, Muhammad Ali, Abdulla Sher, Mahkam Mahmudov, Yanglish Egamova, Shoazim Munavvarov, Suvon Meli, Mirzaali Akbarov and Zuhriddin Isomiddinov who had written textbooks and manuals with masters who knew foreign languages. An example is the textbook "Introduction to the specialty of translation" by Ibrahim Gafurov, who for many years taught students the theory and practice of translation at the National University of Uzbekistan and UzSWLU. Ten years ago, in a roundtable discussion, SuvonMeli, a well-known literary critic, said: "Here we are in the first seven years of the new 21st century. A question still remains: can we conquer the peaks we conquered in the last century in the new century? However, reoccupying the occupied peaks is not so much a pleasure. The task is to reach new heights based 
on this height. Today, translation is one of the main factors of interlingual and intercultural communication. In short, translation introduces the nation to the world and opens the way for our direct participation in the process of international globalization. We must never forget this.

There is a saying that - Shakespeare bepoèn... . The word belongs to the pen of the great German poet Johann Wolfgang Goethe. Indeed, the legacy of William Shakespeare, a great exponent of English Renaissance literature and theatrical art, has fascinated the peoples of the world for four centuries. In Uzbekistan, the name of Shakespeare, his works are well-known and popular, deeply rooted in the hearts of readers and viewers. True, it is difficult to imagine Uzbek drama and theatrical art, its development without Shakespeare's legacy. The king that Shakespeare created in the last eighty yearsalmost all of the works have been translated into our language and presented to our readers in a number of publications. During the period of independence, the "Science" publishing house did another good deed in this regard by publishing a three-volume "Selection" of Shakespeare's works translated by the poet Jamal Kamal. By the way, the People's Poet of Uzbekistan, the well-known translator Jamal Kamal was not only envious of Shakespeare's legacy, but also, as a creator, considered himself to be related to his spiritual world andheir (G. Salomov, B. Nazarov). Yes, the poet studied his legacy diligently before embarking on a translation of Shakespeare's work, lecturing to institute students on the history of English literature. Jamol aka recalls his first experience, when he went to the famous actor Olim Khodjaev with the translation of the tragedy "Macbeth" under his arm: "I remember," says the poet. - I translated Macbeth and took him to Olim Khodjaev. His eyes twinkled as he read Shakespeare's name. He stood up, read the manuscript, and stared into her eyes.

Now a word about the translations of the poet Jamal Kemal.It is known that any translation serves as a product of its time, as an example of national literature. If it becomes a true work of art, it can live for centuries and become a free example of classical literature. For example, translations from the history of Uzbek translation literature by Ogahiy, Cholpon, Oybek, Usmon Nosir, Gafur Gulom, Mirtemir, Mirzakalon Ismoiliy, Ozod Sharofiddinov, ErkinVahidov, Abdulla Aripov, Qodir Mirmuhamedov, Ibrahim Gafurov. If we talk about the experience of translating from Shakespeare's works, the tragedy of the author of Hamlet (Hamlet, 1600-1601) is the most widely translated work in the world languages. Indeed, the point that touches the heart of the reader and the spectator in the play is Hamlet's monologue. The question of "Yo hayot, yo momot" was confronted by Hamlet, who was stunned by the bitter truth that he had clashed with innumerable fikh and struck the pure notions of being and man. In fact, an exciting monologue beginning with the lines - To be, or not to be: that is the question in Russian translations: -Быть или не быть? Вот в чем вопрос! (M. Vronchenko, 1829); -Быть или не быть? Вот в чем вопрос!(А. Kroneberg, 1844); -Быть или не быть? Вот в чем вопрос!(M.Lozinskiy, 1933); -Быть или не быть? Вот в чем вопрос!(В. Pasternak, 1940) was translated in almost the same pattern, but Uzbek translators translated it in different forms. The monologue is translated by Cholpon as Yo hayot, yo o'lim masala shunda; In M. Shakhzoda's translation, "To survive or to die?" That's the problem! " Jamal Kamal translated it as "Yo hayot, yo o'lim masala shunda"

On the purely linguistic problems of translation theoryHundreds of well-known scientists, independent researchers and masters presented their papers at scientific conferences held last year at the National University of Uzbekistan and Andijan State Universityparticipated. In them we see that the topical issues of modern translation studies are studied in a purely theoretical plan. Also in December 2015 at Andijan State University was held a seminar on "Linguo cognitive, 
communicative and pragmatic translation." And 135 reports were presented at the Republican scientific-practical conference on "Linguo cultural aspects".

Admittedly, most of the speeches at the conference were based on theories and theses based on the theory of Western and Russian linguistics and translation studiestakes over. In them we find that ideas about the practice and critique of literary translation are seldom discussed.

Unfortunately, no one from the Writers' Union's Literary Relations and Literary Translation Department or the World Literature Magazine took part in the conference.

Indeed, the fact that well-known translators such as I. Gafurov, N. Kamilov, A. Fayzulla, A. Sher, M. Mirzo, M. Akbarov, Ya. Egamova were not invited also creates a gap between theory and practiceindicates that the gap between practice and theory also has a negative effect on translation criticism.

\section{Conclusion}

In conclusion, we can say that the best works of world literature are being translated into our language and finding their readers. Our intention is that these translations should also find their place in the science of translation criticism and theory, and that practice, theory and criticism would be an excellent light upon light if they serve the same purpose.

\section{References}

[1] Abdurahmonov G., Shukurov Sh. (1973), Historical grammar of the Uzbek language. Morphology and syntax. T .: Teacher, p.320

[2] Abdurahmonov G., Rustamov (1982), A. Ancient Turkic language. $\mathrm{T}$.: Teacher, p. 168

[3] Abdurahmonov N, (1989), Ancient Turkic language. $\mathrm{T} .:$ Teacher, p. 160

[4] Abuzalova M.Q. (2005), Modern Uzbek language. Morphology. Educational- methodical manual for bachelor's degree in Uzbek philology, Bukhara, p.140

[5] Azizov O, (1996), Introduction to Linguistics. $\mathrm{T}$.: Teacher, p.76

[6] Asadov T, (2010), In the system of word categories. Monograph. $\mathrm{T}$ : Muharrir, $\mathrm{p}$. 132

[7] Askarova M, Yunusov R (2007), Uzbek language practicum. Jizzakh

[8] Ashirboev S., Azimov I. (2002), Historical grammar of the Uzbek language. (manual). T .: Fan, p. 137

[9] Eltazarov J.D. (2003), Interactions and migrations in the paradigm of word groups in the Uzbek language. $\mathrm{T}$.: National Encyclopedia of Uzbekistan, p.135

[10] Hojiev A. (1989), Uzbek word formation. T $\therefore$ Teacher, p. 112

[11] 11. Kemal F., (1957), Modern Uzbek literary language. T.$:$ Fan, p. 470 